\title{
Učinek računalniškega kognitivnega treninga prostorske navigacije na kognitivne sposobnosti pri nadarjenih učencih
}

\author{
Barbara Slatenšek ${ }^{1 *}$, Vojko Kavčič ${ }^{, 3}$ in Karin Bakračevič ${ }^{4}$ \\ ${ }^{1}$ Ekonomska šola Celje \\ ${ }^{2}$ Institute of Gerontology, Wayne State University, Detroit, Michigan, ZDA \\ ${ }^{3}$ Mednarodni inštitut za aplikativno gerontologijo, Ljubljana \\ ${ }^{4}$ Oddelek za psihologijo, Filozofka fakulteta, Univerza v Mariboru
}

Povzetek: Prostorska navigacija je kompleksna kognitivna sposobnost, ki je nujna za vsakodnevno delovanje v okolju in je odvisna od širokega spektra kognitivnih sposobnosti. Namen pričujoče raziskave je bil preveriti učinek računalniškega kognitivnega treninga prostorske navigacije na povečanje obsega kratkoročnega spomina, delovnega spomina, vidnoprostorskega spomina in besednega spomina ter na izboljšanje hitrosti procesiranja informacij in izvršilnih funkcij pri nadarjenih učencih. V raziskavi je sodelovalo 28 učencev iz 5. in 6. razreda osnovne šole, ki so bili identificirani kot nadarjeni učenci na različnih področjih in so na testu inteligentnosti (Standardne progresivne matrike [SPM]) dosegli nadpovprečen rezultat. V eksperimentalni skupini (13 učencev) so nadarjeni učenci izvajali kognitivni trening $\mathrm{z}$ nalogami virtualnega labirinta $\mathrm{v}$ osmih srečanjih po 45 minut enkrat tedensko, medtem ko je bila kontrolna skupina pasivna. Rezultati so pokazali, da je bil kognitivni trening učinkovit, saj so nadarjeni učenci v eksperimentalni skupini v primerjavi z učenci iz kontrolne skupine po končanem treningu z virtualnim labirintom dosegli statistično pomembno boljše rezultate pri hitrosti procesiranja in pri takojšnjem priklicu vidnoprostorskega spomina. Rezultati naše raziskave kažejo na učinkovitost kognitivnega treninga tudi pri nadarjenih učencih z višjimi kognitivnimi sposobnostmi.

Ključne besede: prostorska navigacija, kognitivni trening, virtualni labirint, kognitivne sposobnosti, nadarjeni učenci

\section{The effect of computerized cognitive training of spatial navigation on cognitive abilities in gifted pupils}

\author{
Barbara Slatenšek $^{1^{*}}$, Vojko Kavčič ${ }^{2,3}$ and Karin Bakračevič ${ }^{4}$ \\ ${ }^{1}$ Celje School of Economics, Slovenia \\ ${ }^{2}$ Institute of Gerontology, Wayne State University, Detroit, Michigan, USA \\ ${ }^{3}$ International Institute of Applied Gerontology, Ljubljana, Slovenia \\ ${ }^{4}$ Department of Psychology, Faculty of Arts, University of Maribor, Slovenia
}

\begin{abstract}
Spatial navigation is a complex cognitive skill and one that is necessary for daily activities in any environment. It depends on a wide spectrum of cognitive abilities. The purpose of the study was to examine whether cognitive training of spatial navigation with gifted students can improve their capacity of short-term memory, working memory, visuospatial memory, and verbal memory, along with increasing the speed of processing and executive functions. Twenty-eight fifth- and sixth-grade pupils who had been identified as gifted and had scored above average on Standard Progressive Matrices (SPM) intelligence test took part in the study. Thirteen gifted students were included in the experimental group in which they trained virtual maze navigation in 8 sessions each lasting 45 minutes per week. The rest of the gifted students $(n=15)$ were assigned to the passive control group. Results showed that cognitive training was effective since the students in the experimental group as compared with the students from the control group achieved significantly better results after cognitive training on the tests measuring processing speed and immediate recall of visuospatial information. The improved performance of these cognitive abilities demonstrates that the cognitive training is effective with gifted students. Thus, the application of cognitive training seems sensible with gifted students even though they already possess advanced cognitive capacities.
\end{abstract}

Keywords: spatial navigation, cognitive training, virtual maze, cognitive abilities, gifted pupils

\footnotetext{
"Naslov/Address: mag. Barbara Slatenšek, Ekonomska šola Celje, Gimnazija in srednja šola, Kosovelova ulica 4, 3000 Celje, e-mail: barbara.slatensek@gmail.com
}

Članek je licenciran pod pogoji Creative Commons Attribution 4.0 International licence. (CC-BY licenca). The article is licensed under a Creative Commons Attribution 4.0 International License (CC-BY license). 
Raziskovalci, ki poročajo o pozitivnih učinkih kognitivnih treningov, se opirajo predvsem na rezultate, ki kažejo izboljšave na treniranih nalogah (npr. Gray idr., 2012) ali netreniranih nalogah, ki merijo enako kognitivno sposobnost, kot so jo udeleženci urili na kognitivnem treningu (npr. Anga idr., 2015; Barnes idr., 2016). Najbolj zaželeni pa so treningi, ki bi omogočili prenos učinkov tudi na druge kognitivne sposobnosti, ki jih ne treniramo neposredno. Prav kognitivni trening prostorske navigacije daje upanje, da bi z njim lahko dosegli daljni transfer. Prostorska navigacija je namreč kompleksna kognitivna sposobnost, ki je odvisna od delovanja širokega spektra kognitivnih sposobnosti, vključno s hitrostjo procesiranja (Moffat idr., 2006), vidnoprostorskimi sposobnostmi (Fenner idr., 2000; Nori idr., 2006), delovnim spominom, kratkoročnim spominom, izvršilnimi funkcijami (Moffat, 2009) in besednim spominom (Miller idr., 2013; Piccardi idr., 2015).

Število raziskav, ki so preučevale učinek kognitivnega treninga, ki vključuje naloge prostorske navigacije, je zelo majhno. Lövdén idr. (2012) so na vzorcu mladih odraslih (starih 20-30 let) in starejših odraslih (starih 60-70 let) ugotovili, da je računalniški trening prostorske navigacije, ki so ga štiri mesece izvajali vsak drugi dan, izboljšal sposobnost prostorske navigacije po treningu. Podobno poročajo Hötting idr. (2013), ki so udeležence po petmesečni redni telesni aktivnosti razdelili v skupino, ki je bila deležna enomesečnega računalniškega treninga prostorske navigacije, in v skupino, ki je bila deležna enomesečnega treninga zaznavanja. Pokazalo se je, da so sposobnost prostorske navigacije izboljšali samo tisti, ki so bili deležni treninga prostorske navigacije. Podoben kognitivni trening prostorske navigacije, ki smo ga uporabili $\mathrm{v}$ naši raziskavi, so predhodno že uporabili Marusic idr. (2016) na vzorcu 16 zdravih odraslih moških. Po 12 srečanjih so rezultati eksperimentalne skupine $\mathrm{v}$ primerjavi s kontrolno skupino pokazali statistično pomembno izboljšanje delovanja izvršilnih funkcij. Statistično pomembna razlika se ni pokazala pri besednem spominu, delovnem spominu in hitrosti procesiranja, kljub temu pa se je pri eksperimentalni skupini pokazal napredek na vseh treh področjih.

$\mathrm{Ob}$ potencialni možnosti, da lahko s kognitivnim treningom prostorske navigacije izboljšamo več kognitivnih sposobnosti, se zdi tak kognitivni trening uporaben tudi kot oblika dela z nadarjenimi učenci. Raziskovalci, ki se ukvarjajo s preučevanjem vzgojno-izobraževalnega dela $\mathrm{z}$ nadarjenimi učenci, namreč opozarjajo na potrebo po novih oblikah dela z nadarjenimi učenci, ki bi potekale izven pouka in bi omogočale razvijanje njihovih potencialov (Juriševič, 2011).

\section{Nadarjeni učenci}

Opredeljevanje nadarjenosti v vzgojno-izobraževalnem smislu se med različnimi državami razlikuje. Opaziti je razpon od strožjih psihometričnih definicij in poudarjanja potencialov učencev, merjenih izključno s testi intelektualnih sposobnosti, do širših definicij, ki temeljijo na razvojni paradigmi in zajemajo poleg intelektualnih sposobnosti tudi druge, neintelektualne spremenljivke. V Sloveniji izhajamo iz opredelitve, da so nadarjeni učenci tisti, ki so po določenih nacionalnih kriterijih visoko nadpovprečni in jih je v populaciji do 10 odstotkov. Nadpovprečnost se ocenjuje glede na dosledne dosežke teh učencev na intelektualnem, ustvarjalnem, učnem, umetniškem in telesno-gibalnem področju (Juriševič, 2011).

Delo $\mathrm{z}$ nadarjenimi učenci $\mathrm{v}$ osnovni šoli ima velik vpliv na njihov uspešen razvoj in napredek (Novak, 2003). Nadarjenost namreč ni stalna oziroma absolutna človekova značilnost in se lahko ob primernih spodbudah razvija (Žagar, 2012). Prav tako pa je pomembno, da se spremljajo in evalvirajo učinki dela $\mathrm{z}$ nadarjenimi učenci, saj se na podlagi slednjih lahko načrtujejo izboljšave in morebitne spremembe (Juriševič, 2011). Kot poročata Willis in Schaie (2009), je prednost računalniških kognitivnih treningov v računalniških algoritmih, ki omogočajo individualiziran kognitivni trening za vsakega posameznika posebej. Omogočajo namreč postopno razvijanje težavnosti nalog glede na uspešnost posameznika, kar vpliva na povečano motivacijo pri reševanju nalog.

\section{Prostorska navigacija}

Osmisliti prostorske informacije, si jih predstavljati in transformirati, so vsakodnevni procesi, ki so ključni za navigiranje po prostoru. Prostorska navigacija je proces, v katerem posameznik integrira pomembne informacije iz okolja in z njimi manipulira skozi prostor in čas (Wolbers in Hegarty, 2010). Med prostorsko navigacijo posameznik pridobiva, kodira, shranjuje, obnavlja in dekodira informacije o relativnem položaju telesa, smeri in cilju poti (Bohbot idr., 2012). Po Wolbersu in M. Hegarty (2010) navigacija po prostoru poteka na več soodvisnih ravneh. Sprva poteka prepoznava prostorskih informacij, ki so kodirane preko senzornih izkušenj. Nadalje vključuje sposobnost oblikovanja mentalnih prostorskih predstav zunanjega okolja in kot zadnje uspešnost uporabe teh predstav pri navigiranju po prostoru.

$\mathrm{Za}$ preučevanje sposobnosti prostorske navigacije se uporabljajo različne navigacijske naloge. V pričujoči raziskavi smo uporabili kognitivni trening prostorske navigacije, ki je sestavljen iz nalog virtualnih labirintov. Le-te pri reševanju zahtevajo različne kognitivne procese: a) odločanje na vsakem križišču labirinta, b) zapomnitev prostorskih oznak in njihovega vrstnega reda, c) povezovanje posameznih prostorskih oznak z informacijami o smeri, d) pomnjenje napačno izbranih poti, e) utrjevanje informacij o labirintu in kodiranje novih informacij (Tom in Tversky, 2012). Med reševanjem navigacijskih nalog se zahteva tudi pravilna raba računalniške tipkovnice ob sočasnem premikanju po virtualnem prostoru.

Namen raziskave je bil preveriti učinek računalniškega kognitivnega treninga prostorske navigacije na kognitivne sposobnosti pri nadarjenih učencih. Zanimalo nas je, ali lahko s kognitivnim treningom prostorske navigacije vplivamo na izboljšanje (1) hitrosti procesiranja informacij in (2) hitrosti delovanja izvršilnih funkcij ter na povečanje (3) obsega kratkoročnega spomina, (4) delovnega spomina, (5) vidnoprostorskega spomina in (6) besednega spomina pri nadarjenih učencih. 


\section{Slika 1}

Prikaz perspektive znotraj virtualnega labirinta - prikaz približevanja križišču z unikatnima slikama (levo) in prikaz slepe ulice (desno; Brain powered games; Michigan State University, Games for Entertainment and Learning Lab, 2016)
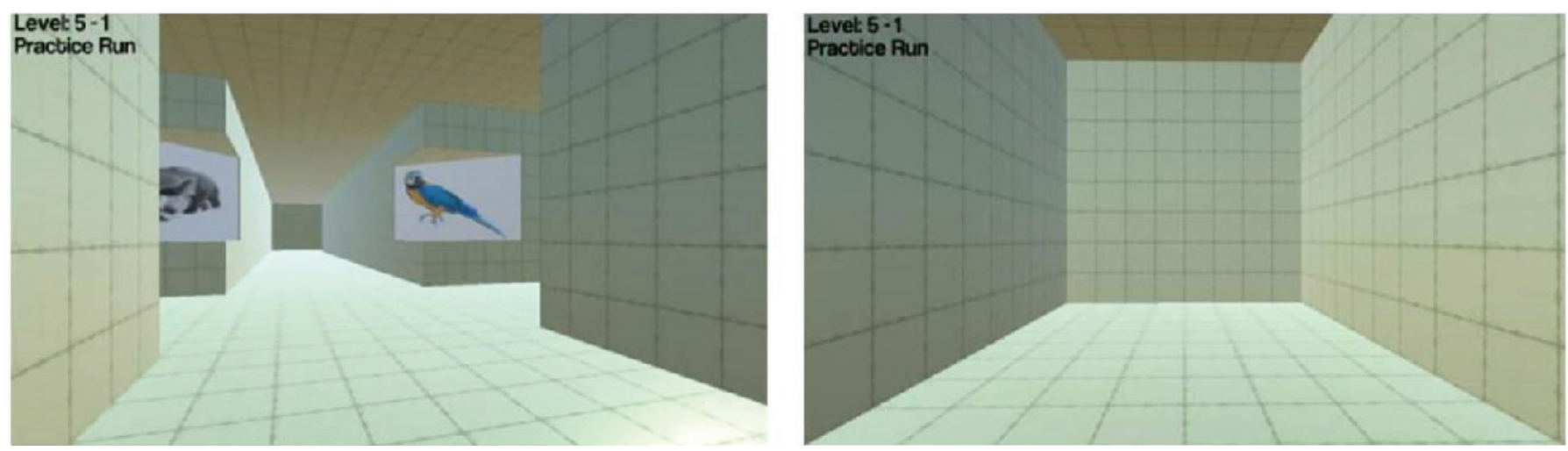

\section{Metoda}

\section{Udeleženci}

Udeleženci raziskave so bili učenci 5. in 6. razreda osnovne šole, ki so bili v 4. razredu identificirani kot nadarjeni učenci, prav tako so istega leta reševali test inteligentnosti Standardne progresivne matrice (SPM) $\mathrm{z}$ namenom ugotavljanja nadarjenosti. $\mathrm{Z}$ namenom pridobiti čim bolj homogen vzorec, smo $\mathrm{v}$ raziskavo vključili samo tiste nadarjene učence, ki so na testu inteligentnosti dosegli vsaj nadpovprečen rezultat oziroma so se uvrstili $v$ vsaj 75. percentil. To ne pomeni, da so $\mathrm{v}$ raziskavo zajeti samo učenci, ki so bili identificirani kot nadarjeni na intelektualnem področju (kriterij zanj je namreč uvrstitev v vsaj 90. percentil oz. izjemno nadpovprečen rezultat), ampak učenci, ki so bili identificirani kot nadarjeni na katerem koli področju (intelektualnem, ustvarjalnem, učnem, umetniškem in/ali telesno-gibalnem področju) in so hkrati na testu inteligentnosti dosegli vsaj nadpovprečen rezultat (uvrstitev $\mathrm{v}$ vsaj 75 . percentil).

$\mathrm{V}$ raziskavo je bilo najprej vključenih 32 učencev (16 deklet in 16 fantov), vendar je zaradi osipa končni vzorec obsegal 28 udeležencev (13 deklet in 15 fantov), starih povprečno 11 let $(S D=0,74)$. Končni vzorec eksperimentalne skupine je zajemal 13 udeležencev ( 6 deklet in 7 fantov, $M_{\text {starost }}=11$ let, $\left.S D=0,76\right)$, medtem ko je končni vzorec kontrolne skupine zajemal 15 udeležencev (7 deklet in 8 fantov, $M_{\text {starost }}=11$ let, $\left.S D=0,74\right)$.

Končni vzorec eksperimentalne skupine je zajemal tri udeležence, ki so se na testu inteligentnosti uvrstili med 75. in 90. percentil, tri udeležence, ki so se uvrstili med 90. in 95. percentil, in sedem udeležencev, ki so se uvrstili nad 95. percentil. Končni vzorec kontrolne skupine je zajemal pet udeležencev, ki so se uvrstili med 75. in 90. percentil, štiri udeležence, ki so se uvrstili med 90 . in 95 . percentil, in šest udeležencev, ki so se uvrstili nad 95. percentil.

V eksperimentalni skupini je sodelovalo 10 učencev, ki so bili identificirani kot nadarjeni učenci na intelektualnem področju (dva od teh tudi na drugem področju), in trije učenci, ki so bili identificirani kot nadarjeni na drugih področjih (na ustvarjalnem, učnem, umetniškem ali telesnogibalnem področju), medtem ko je v kontrolni skupini sodelovalo 10 učencev, ki so bili identificirani kot nadarjeni na intelektualnem področju, in pet učencev, ki so bili identificirani na drugih področjih.

Nihče izmed udeležencev ni imel okvare vida oziroma je okvaro korigiral z nošenjem korekcijskih očal. Vsi udeleženci so imeli dobro razvito gibljivost zgornjih udov za nemoteno uporabo tipkovnice. Nihče izmed njih $\mathrm{v}$ času intervencije ni užival zdravil, ki bi lahko vplivala na reševanje kognitivnih nalog, prav tako nihče prej ni izvajal kognitivnega treninga.

\section{Pripomočki}

\section{Računalniški kognitivni trening prostorske navigacije}

$\mathrm{V}$ raziskavi smo uporabili kognitivni trening virtualne prostorske navigacije, ki temelji na računalniškem programu Brain powered games: Maze training (Michigan State University, Games for Entertainment and Learning Lab, 2016). Kognitivni trening je oblikovan na način, da se vsak udeleženec individualno premika $\mathrm{v}$ virtualnem okolju labirintov. Po labirintu se premika s pomočjo smernih puščic na tipkovnici. Na vsakem križišču lahko izbira med tremi smermi (levo, naravnost in desno), pri čemer je le ena smer pravilna in vodi do naslednjega križišča, medtem ko ostali smeri vodita $\mathrm{v}$ slepo ulico. Na vsakem križišču sta unikatni sliki živali, ki služita za orientacijo pri zapomnitvi poti (slika 1 - levo).

Kognitivni trening je sestavljen iz več težavnostnih stopenj. Pred začetkom vsake težavnostne stopnje mora udeleženec najprej poiskati pravilno pot iz labirinta. Ko udeleženec odkrije pravilno pot oziroma pride do cilja (cilj predstavlja pokal na koncu labirinta), mora $\mathrm{v}$ naslednjih dveh zaporednih nizih brez napake priti do cilja. V primeru, da udeleženec $\mathrm{v}$ drugem zaporednem nizu naredi napako, mora pravilno pot zopet ponoviti $\mathrm{v}$ dveh zaporednih nizih. Udeleženec se torej na določeni težavnostni stopnji zadržuje toliko časa, da v dveh zaporednih nizih brez napake pride do cilja. Brez napake pomeni, da udeleženec med potjo nikoli 
ne zavije v napačno smer oz. si je pravilno zapomnil celotno pot iz labirinta. Po uspešno zaključeni težavnostni stopnji se trening nadaljuje na naslednji težavnostni stopnji. Vsaka naslednja težavnostna stopnja vsebuje eno križišče več, kar pomeni, da si je potrebno zapomniti vedno daljšo pot iz labirinta.

Na treningu so udeleženci začeli na 3. težavnostni stopnji oziroma z labirintom s tremi križišči. Napredovali so lahko do 9. težavnostne stopnje. Vsak je prejel svojo šifro, s katero se je vpisal v računalniški program. Program je na podlagi unikatne šifre beležil napredek udeleženca, tako da je na naslednjem srečanju lahko nadaljeval trening tam, kjer je predhodno končal.

\section{Test sledenja}

Test sledenja (angl. Trail Making Test - TMT; Partington in Leiter, 1938, citirano v: Lezak idr., 2012) je nevropsihološki instrument, ki meri hitrost procesiranja in izvršilne funkcije. Obsega dva dela. V prvem delu (A) mora testiranec oštevilčene kroge, razporejene na A4 formatu papirja, povezati $\mathrm{V}$ pravilnem vrstnem redu (od 1 do 25). V drugem delu (B) mora na enak način povezati kroge, pri čemer so v nekaterih zapisane številke (od 1 do 13), v nekaterih pa črke (od A do L). Testiranec mora preklapljati med pravilnim vrstnim redom številk in abecednim redom črk (1, A, 2, B itn.). Naloga testiranca pri obeh delih je, da kroge povezuje čim hitreje, pri čemer ne sme dvigovati svinčnika s papirja. Rezultat predstavlja skupni čas reševanja, izmerjen v sekundah, pri čemer nižji rezultat pomeni boljšo izvedbo. Čas, izmerjen v delu A, predstavlja hitrost procesiranja informacij; razlika $\mathrm{v}$ času med delom B in delom A predstavlja hitrost delovanja izvršilnih funkcij.

Koeficienti zanesljivosti Testa sledenja se med raziskavami razlikujejo in so običajno nižji za del A (Strauss idr., 2006). Za del A se gibljejo od nizkih vrednosti $(r=0,36)$ do zelo visokih $(r=0,94)$. Pri delu B se koeficienti zanesljivosti gibljejo od 0,65 navzgor (Goldstein in Watson, 1989).

\section{Test kompleksih figur}

Test kompleksnih figur (angl. The Rey-Osterrieth complex figure test-ROCF; Rey, 1941, citirano v: Lezak idr., 2012) meri zaznavno organizacijo in vidnoprostorski spomin. Test se izvaja v treh pogojih. V prvem pogoju pred testiranca postavimo sliko s kompleksno figuro (slika različno dolgih in različno usmerjenih črt, povezanih v figuro). Damo mu papir in svinčnik ter navodilo, da figuro čim bolj natančno preriše. Ko testiranec zaključi s prerisovanjem, figuro in kopijo odstranimo. Po treh minutah testiranca prosimo, da skuša čim bolj natančno narisati figuro po spominu. Sledi tretji pogoj, ko testiranec čez 20 minut ponovno nariše figuro po spominu. Testiranec ni časovno omejen v nobenem pogoju.

Narisane figure iz vseh treh pogojev smo točkovali na podlagi liste za točkovanje, ki jo je razvil Taylor (1998, citirano v: Lezak idr., 2012). Vrednoti se natančna reprodukcija in postavitev 18 specifičnih elementov figure (npr. križ, mali kvadrat, navpična črta itd.). Vsak element točkujemo z 2, 1, 0,5 ali 0 točkami. Dve točki dodelimo v primeru natančne reprodukcije elementa in pravilne postavitve $\mathrm{v}$ figuri, eno točko v primeru natančne reprodukcije in napačne postavite ali nenatančne reprodukcije in pravilne postavitve v figuri, pol točke v primeru nenatančne reprodukcije, vendar prepoznane in napačne postavitve ter nič točk v primeru neprepoznane reprodukcije in napačne postavitve. Maksimalno doseženo število točk za vsako risbo je 36. Skupno število točk drugega pogoja (risanje figure po treh minutah) nam poda mero takojšnjega priklica; skupno število točk tretjega pogoja (risanje figure po 20 minutah) nam poda mero odloženega priklica.

Berry idr. (1991, citirano v Lezak idr., 2012) poročajo o sprejemljivi zanesljivosti testa, ki so jo merili $\mathrm{z}$ metodo alternativne oblike, in sicer so se koeficienti zanesljivosti gibali med 0,60 in 0,76 .

\section{Ponavljanje številk}

Ponavljanje številk je podtest Wechslerjeve lestvice inteligentnosti za otroke - WISC-III ${ }^{\text {SI }}$ (Wechsler, 2001). Test meri obseg kratkoročnega in delovnega spomina. Sestavljen je iz dveh delov (ponavljanje številk naprej in ponavljanje številk nazaj). Testator bere nepretrgan niz številk, in sicer eno številko na sekundo. Testiranec mora vsak niz ponoviti $\mathrm{v}$ istem (Naprej) in obrnjenem zaporedju (Nazaj). Vsaka naloga je sestavljena iz dveh poskusov, pri čemer vsak poskus vsebuje isto količino številk (od 2 do 9 številk pri delu Naprej in od 2 do 8 številk pri delu Nazaj). Reševanje nalog Naprej se ustavi, ko testiranec pri obeh poskusih katere koli naloge naredi napako. Potem nadaljujemo z nalogami Nazaj, dokler se testiranec ne zmoti pri obeh poskusih katere koli naloge.

Rezultate nalog Naprej in Nazaj se sešteva posebej. Dve točki se dodelita za pravilno ponovitev obeh poskusov, ena točka za pravilno ponovitev enega poskusa in nič točk za napačno ponovitev obeh poskusov (Wechsler, 2001). Skupni rezultat pri delu Naprej je vsota točk nalog in kaže obseg kratkoročnega spomina. Skupni rezultat pri delu Nazaj je vsota točk nalog in kaže manipulacijo števil v delovnem spominu s pomočjo vizualne predstave informacij (Kaufman, 1994).

Wechsler (2001) poroča o visokem koeficientu razpolovitve $(r=0,85)$ in sprejemljivi notranji konsistentnosti $(\alpha=0,68)$.

\section{Test slušno-besednega učenja}

Test slušno-besednega učenja (angl. Auditory-Verbal Learning Test - AVLT; Ray, 1964, citirano v: Lezak idr., 2012; Taylor, 1959, citirano v: Lezak idr., 2012) meri priklic besed s preobremenitvijo, končni obseg besednega spomina, krivuljo učenja, odložen priklic, proaktivno in retroaktivno interferenco, kaže na prisotnost ali odsotnost strategij učenja in dovzetnost za moteče dražljaje. V raziskavi smo uporabili skrajšano različico testa, ki vsebuje tri poskuse. V prvem delu testa testirancu preberemo seznam petnajstih besed (lista A), pri čemer beremo eno besedo na sekundo. Naloga testiranca je, da ponovi čim več besed ne glede na vrstni red (P-1). Sledita dva poskusa ponovnega branja istega seznama in ponoven priklic besed ne glede na vrstni red (P-2 in $\mathrm{P}-3$ ). 
Rezultat vsakega poskusa predstavlja število pravilno priklicanih besed. Višji rezultat pomeni boljšo izvedbo. Obseg besednega spomina s preobremenitvijo predstavlja vsota pravilno priklicanih besed $\mathrm{v}$ prvem poskusu (P-1). Končni obseg besednega spomina predstavlja zadnji poskus pred listo B (P-3 $3^{1}$ Ray, 1964, citirano v: Lezak idr., 2012; Taylor, 1959, citirano v Lezak idr., 2012).

Delaney idr. (1992, citirano v: Lezak idr., 2012) poročajo o sprejemljivi do dobri zanesljivosti testa AVLT. Po metodi alternativne oblike so se korelacije merjenih prvih treh poskusov in alternativnih oblik $\mathrm{v}$ razmiku enega meseca gibale med 0,61 in 0,86 .

\section{Postopek}

Po odobritvi vodstva šole za izvajanje raziskave smo pri šolski svetovalni službi prosili za anonimizirane podatke o nadarjenih učencih, ki so obiskovali 5. in 6. razred. V raziskavo smo vključili nadarjene učence, ki so se na testu inteligentnosti uvrstili v 75. percentil ali višje ter jih razvrstili $\mathrm{v}$ eksperimentalno in kontrolno skupino, in sicer tako, da je vsako skupino sestavljalo enako število deklet in fantov. Učencem, ki so bili vključeni v raziskavo, smo razdelili obveščeno soglasje za starše o sodelovanju njihovega otroka $\mathrm{v}$ raziskavi, ki so jih posredovali staršem. Izvajanje raziskave je trajalo tri mesece; od tega je bil en mesec namenjen testiranju pred intervencijo in po njej, dva meseca pa izvedbi intervencije. V začetni fazi smo izvedli individualna testiranja s kognitivnimi testi pri obeh skupinah, ki so trajala 25-30 minut.

Kognitivni treningi $\mathrm{z}$ eksperimentalno skupino so potekali $\mathrm{v}$ različnih terminih, $\mathrm{z}$ enim do štirimi učenci na termin. Če se učenec ni mogel udeležiti določenega termina, smo določili nov termin, ki od predvidenega ni bil zamaknjen za več kot tri dni. Vsak udeleženec eksperimentalne skupine je prejel svoj namizni računalnik $\mathrm{z}$ naloženim programom kognitivnega treninga in šifro, $\mathrm{s}$ katero se je vpisoval $\mathrm{v}$ računalniški program. Učenci so kognitivni trening reševali $\mathrm{v}$ za to posebej namenjeni učilnici.

Trening je potekal $\mathrm{v}$ osmih srečanjih, in sicer enkrat tedensko po 45 minut. Kontrolna skupina je bila v tem času pasivna. Po opravljenem kognitivnem treningu je sledilo ponovno individualno testiranje kognitivnih sposobnosti tako pri eksperimentalni kot pri kontrolni skupini. Individualno testiranje se je začelo en teden po končanem treningu in je trajalo dva tedna.

Začetno in končno testiranje je potekalo $\mathrm{z}$ enakimi kognitivnimi testi. Vrstni red reševanja testov je bil pri obeh testiranjih sledeč: najprej je testiranec opravil prvi poskus Testa kompleksnih figur (prerisovanje figure), sledil je test Ponavljanje številk, in sicer del Naprej in del Nazaj, nato je

\footnotetext{
${ }^{1}$ Običajno končni obseg besednega spomina predstavlja peti poskus, ki je tudi zadnji poskus pred listo B (Ray, 1964, citirano v: Lezak idr., 2012; Taylor, 1959, citirano v: Lezak idr., 2012). V raziskavi smo uporabili skrajšano različico, zato smo za mero končnega obsega besednega spomina uporabili tretji poskus.
}

udeleženec opravil drugi poskus Testa kompleksnih figur (risanje po spominu čez 3 minute). Sledila je izvedba Testa slušno-besednega učenja (AVLT) in nato tretji poskus Testa kompleksnih figur (risanje po spominu čez 20 minut). Na koncu je sledilo reševanje Testa sledenja (TMT-A in nato TMT-B; slika 2).

\section{Statistična obdelava podatkov}

Pridobljeni podatki so bili statistično obdelani $\mathrm{Z}$ računalniškim programom IBM SPSS (verzija 21). S Shapiro-Wilkovim testom smo preverili, ali so odvisne spremenljivke porazdeljene normalno. Dodatno smo pregledali meri asimetričnosti in sploščenosti. S Studentovim $t$-testom za neodvisne vzorce smo preverili izenačenost med eksperimentalno in kontrolno skupino $\mathrm{v}$ dosežkih na kognitivnih testih, ki so jih udeleženci reševali na začetnem testiranju. V nadaljevanju smo s parnim $t$-testom za odvisne vzorce preverili razlike $\mathrm{v}$ dosežkih na kognitivnih testih na začetnem in končnem testiranju (po intervenciji) znotraj posamezne skupine.

Učinek interakcije med časom (pred intervencijo in po njej) in skupino (eksperimentalno in kontrolno) pri različnih odvisnih spremenljivkah smo preverili z dvosmerno analizo variance za mešani načrt. Vrednosti odvisnih spremenljivk so predstavljali dosežki na kognitivnih testih, in sicer dosežek na testu TMT-A, razlika dosežka na testu TMT-B in TMT-A (kar smo označili z TMT_b-a), dosežek na testu Ponavljanje številk naprej, dosežek na testu Ponavljanje številk nazaj, dosežek na drugem in tretjem poskusu testa ROCF ter dosežek na tretjem poskusu testa AVLT. Za vsako odvisno spremenljivko smo izvedli ločeno analizo variance za mešani načrt $(2 \times 2$ načrt), pri čemer je čas (pred intervencijo in po njej) predstavljal faktor znotraj oseb in skupina (eksperimentalna in kontrolna skupina) faktor med osebami.

Pred vsako analizo smo preverili ustreznost podatkov glede na predpostavke ANOVE za mešani načrt. S ShapiroWilkovim testom ter $z$ merama asimetričnosti in sploščenosti smo preverili, ali so vrednosti odvisnih spremenljivk $\mathrm{v}$ obeh skupinah na začetnem in končnem merjenju normalno porazdeljene. $\mathrm{Z}$ Levenovim testom smo preverili, ali so variance $\mathrm{v}$ obeh skupinah med seboj primerljive po velikosti (homogenost varianc). Prav tako smo preverili, ali so $\mathrm{v}$ podatkih osamelci, medtem ko predpostavke o sferičnosti nismo preverjali, ker smo imeli le dve časovni točki merjenja.

Rezultatom smo dodali mere velikosti učinka kot dopolnitev $\mathrm{k} p$-vrednosti. Pri $t$-testu za odvisne in neodvisne vzorce smo izračunali Cohenov $d$-indeks velikosti učinka, pri čemer smo pri interpretaciji učinka upoštevali: $d=0,20$ - majhen učinek; $d=0,50$ - srednji učinek; $d=0,80$ - velik učinek (Cohen, 1992). Pri analizi variance za mešani načrt smo velikost učinka preverjali s parcialnim eta kvadratom, pri čemer smo pri interpretaciji učinka upoštevali: $\eta_{\mathrm{p}}{ }^{2}=0,0099-$ majhen učinek; $\eta_{\mathrm{p}}{ }^{2}=0,0588$ - srednji učinek; $\eta_{\mathrm{p}}{ }^{2}=0,1379$ - velik učinek (Cohen, 1969, citirano v: Richardson, 2011). 


\section{Slika 2}

Potek raziskave

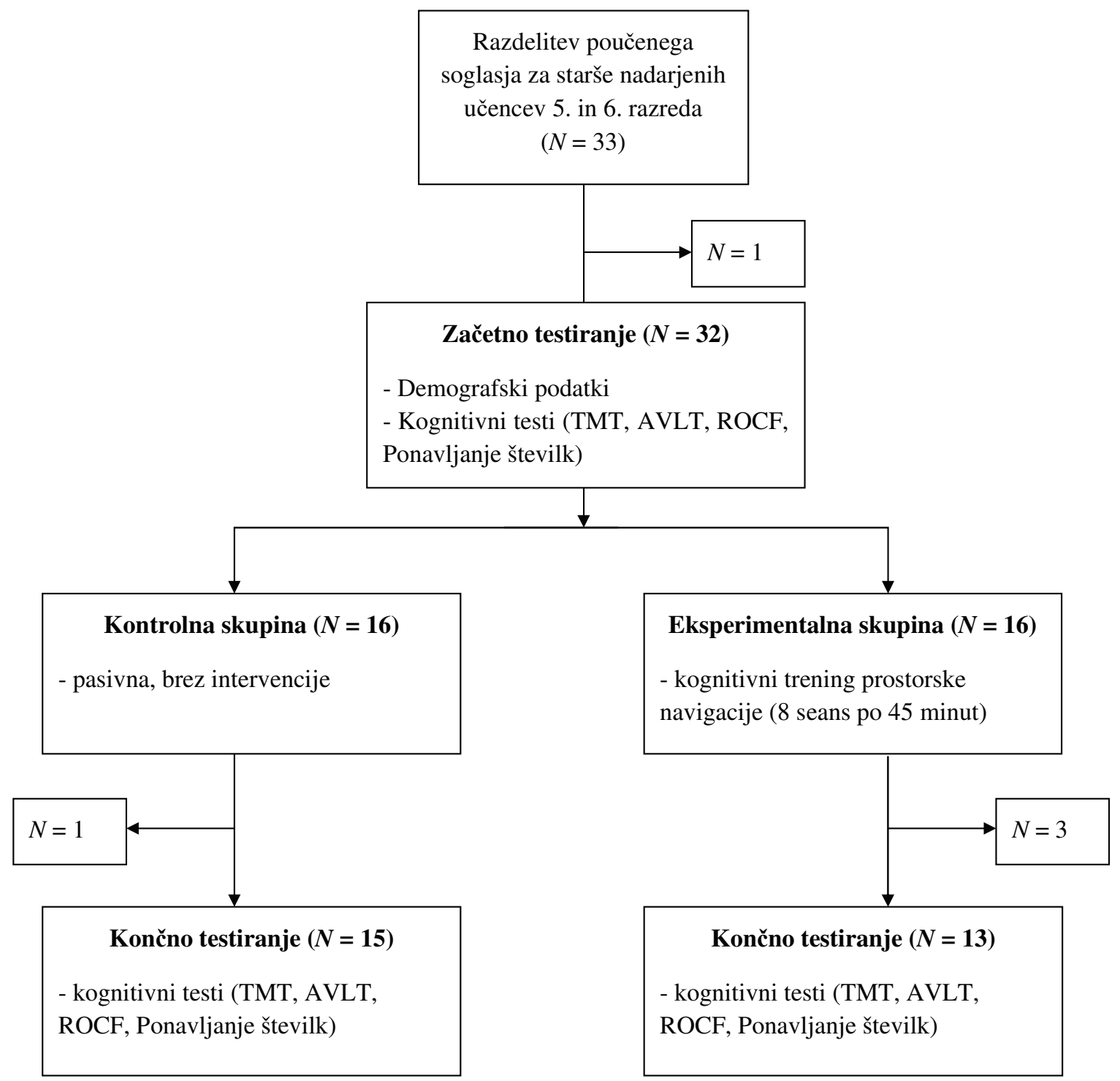

\section{Rezultati in razprava}

Pri nobeni odvisni spremenljivki porazdelitev ni pomembno odstopala od normalne, razen pri dosežkih na TMT_b-a. Poleg tega so se mere asimetričnosti in sploščenosti pri vseh spremenljivkah gibale med vrednostma -2 in 2 . Statistične analize v nadaljevanju smo tako opravili s parametričnimi testi. Rezultati so pokazali, da med eksperimentalno in kontrolno skupino ni bilo statistično pomembnih razlik $\mathrm{v}$ dosežkih na kognitivnih testih začetnega testiranja (tabela 2).

$\mathrm{V}$ tabeli 1 so prikazane osnovne opisne statistike odvisnih spremenljivk za eksperimentalno in kontrolno skupino, ki smo jih izmerili pred intervencijo in po njej, ter rezultati parnih $t$-testov. Parni $t$-test je pri eksperimentalni skupini pokazal, da so udeleženci kognitivnega treninga pomembno izboljšali svoj rezultat na vseh kognitivnih testih. Vse velikosti učinka odvisnih spremenljivk pri eksperimentalni skupini so se gibale od srednjih do velikih učinkov. Pri kontrolni skupini so udeleženci pomembno izboljšali svoj rezultat na drugem testiranju na nalogi delovnega spomina (Nazaj) s srednjim učinkom in na nalogi odloženega priklica vidnoprostorskega spomina (ROCF2) $\mathrm{z}$ velikim učinkom. Pri ostalih nalogah udeleženci niso pomembno izboljšali svojega rezultata na drugem testiranju.

Učinek interakcije med časom (pred intervencijo in po njej) in skupino glede na odvisne spremenljivke smo preverili $\mathrm{z}$ analizo variance za mešani načrt, pri čemer smo za vsako odvisno spremenljivko izvedli ločeno analizo (tabela 3). Porazdelitev dosežkov na nalogi TMT-A ni statistično značilno odstopala od normalne $\mathrm{v}$ nobeni od skupin in časovnih točk merjenja. Predpostavka o homogenosti varianc je bila izpolnjena, saj se variance dosežkov med skupinama pri prvem merjenju $(F[1,26]=1,19, p=0,29)$ in pri drugem merjenju $(F[1,26]=3,65, p=0,07)$ niso statistično značilno razlikovale. Pri pregledu grafičnih prikazov smo našli štiri 
Tabela 1

Opisne statistike dosežkov eksperimentalne in kontrolne skupine na začetnem in končnem testiranju ter rezultati parnih t-testov za primerjavo dosežkov pred intervencijo in po njej

\begin{tabular}{|c|c|c|c|c|c|c|c|}
\hline \multirow[b]{2}{*}{ Spremenljivka } & \multicolumn{2}{|c|}{ Začetno testiranje } & \multicolumn{2}{|c|}{ Končno testiranje } & \multirow[b]{2}{*}{$t$} & \multirow[b]{2}{*}{$p$} & \multirow[b]{2}{*}{$d$} \\
\hline & $M$ & $S D$ & $M$ & $S D$ & & & \\
\hline \multicolumn{8}{|c|}{ Eksperimentalna skupina $(n=13)$} \\
\hline TMT_a & 32,00 & 7,57 & 26,62 & 7,25 & $-4,89$ & $<, 001$ & $-1,36$ \\
\hline TMT_b-a & 38,69 & 19,57 & 29,62 & 13,36 & $-2,26$ &, 044 & $-0,63$ \\
\hline Naprej & 8,62 & 1,85 & 9,85 & 2,61 & 2,36 &, 036 & 0,66 \\
\hline Nazaj & 5,15 & 1,35 & 6,62 & 1,26 & 2,55 &, 025 & 0,71 \\
\hline ROCF1 & 25,39 & 4,82 & 29,19 & 4,55 & 3,31 &, 006 & 0,92 \\
\hline ROCF2 & 25,62 & 4,13 & 28,96 & 5,20 & 2,77 &, 017 & 0,77 \\
\hline AVLT & 11,85 & 1,73 & 13,08 & 1,44 & 2,70 & 019 & 0,75 \\
\hline \multicolumn{8}{|c|}{ Kontrolna skupina $(n=15)$} \\
\hline TMT_a & 33,47 & 10,49 & 33,93 & 10,65 & 0,19 &, 851 & 0,05 \\
\hline TMT_b-a & 34,53 & 13,76 & 32,47 & 15,78 & $-0,48$ & ,640 & $-0,12$ \\
\hline Naprej & 8,47 & 1,13 & 8,80 & 1,67 & 0,55 &, 591 & 0,14 \\
\hline Nazaj & 5,47 & 1,25 & 6,40 & 1,50 & 2,82 &, 014 & 0,73 \\
\hline ROCF1 & 24,33 & 3,94 & 25,60 & 4,54 & 2,11 & 053 & 0,55 \\
\hline ROCF2 & 23,53 & 5,71 & 27,23 & 4,70 & 3,55 &, 003 & 0,92 \\
\hline AVLT & 11,73 & 1,62 & 12,60 & 1,45 & 1,60 & ,132 & 0,41 \\
\hline
\end{tabular}

Opombe. TMT_a = hitrost procesiranja; TMT_b-a = hitrost izvršilnih funkcij; Naprej= obseg števil naprej; Nazaj= obseg števil nazaj; ROCF 1 = obseg vidnoprostorskega spomina po 3 min; ROFC2 = obseg vidnoprostorskega spomina po 20 min; AVLT = obseg besednega spomina (dosežek na tretjem poskusu testa AVLT). Prostostne stopnje za parne $t$-teste pri dosežkih eksperimentalne skupine so znašale 12, pri dosežkih kontrolne skupine pa 14 .

osamelce (tri v eksperimentalni in enega v kontrolni skupini na začetnem testiranju). Dva osamelca $\mathrm{v}$ eksperimentalni skupini nista dosegala ekstremne vrednosti, medtem ko sta $\mathrm{dva}$ - osamelec $\mathrm{v}$ eksperimentalni in osamelec $\mathrm{v}$ kontrolni skupini - dosegala ekstremne vrednosti (odstopanje za več kot 3 IQR, pri čemer je IQR = 3. kvartil - 1. kvartil). Glede na to, da so bili podatki ustrezni glede na ostale pogoje ANOVE za mešani načrt, smo obdržali osamelce in nadaljevali $\mathrm{z}$ analizo variance.

Rezultati so pokazali velik in statistično pomemben učinek interakcije med časom in skupino $\mathrm{v}$ hitrosti procesiranja informacij (TMT-A; slika 3). Prav tako je parni $t$-test pokazal statistično značilno razliko med povprečnima dosežkoma pred treningom in po njem pri eksperimentalni skupini ter zelo veliko velikost učinka. $\mathrm{V}$ nasprotju se pri kontrolni skupini ni pokazala statistično pomembna razlika, povprečen rezultat na končnem testiranju je ostal skoraj nespremenjen, tudi velikost učinka ni bila velika.

Preverili smo, ali se rezultati spremenijo, v kolikor iz analize izločimo osamelca, ki sta dosegala ekstremne vrednosti. Učinek interakcije med časom in skupino je ostal velik oziroma se je še nekoliko povečal in je ostal statistično pomemben, $F(1,24)=4,346, p=0,048, \eta_{p}{ }^{2}=0,153$. Zaključimo lahko, da so udeleženci eksperimentalne skupine v primerjavi s kontrolno pomembno izboljšali dosežke na nalogi TMT-A, ki predstavlja mero hitrosti procesiranja.

Tabela 2

Rezultati t-testov za primerjavo dosežkov eksperimentalne in kontrolne skupine na začetnem testiranju

\begin{tabular}{lrcr}
\hline Spremenljivka & $t(26)$ & $p$ & $d$ \\
\hline TMT_a & $-0,42$ &, 68 & $-0,16$ \\
TMT_b-a & 0,66 &, 52 & 0,25 \\
Naprej & 0,25 &, 80 & 0,10 \\
Nazaj & $-0,64$ &, 53 & $-0,24$ \\
ROCF1 & 0,64 &, 53 & 0,24 \\
ROCF2 & 1,09 &, 29 & 0,41 \\
AVLT & 0,18 &, 86 & 0,07 \\
\hline
\end{tabular}

Opombe. Za razlago oznak testnih dosežkov glej opombe k tabeli 1 .

Tabela 3

Učinek interakcije med časom merjenja in skupino

\begin{tabular}{lccc}
\hline Spremenljivka & $F(1,24)$ & $p$ & $\eta_{\mathrm{p}}^{2}$ \\
\hline TMT_a & 4,30 &, 048 &, 142 \\
TMT_b-a & 1,38 &, 251 &, 050 \\
Naprej & 1,22 &, 280 &, 045 \\
Nazaj & 0,68 &, 417 &, 026 \\
ROCF1 & 4,14 &, 052 &, 137 \\
ROCF2 & 0,05 &, 826 &, 002 \\
AVLT & 0,26 &, 618 &, 010 \\
\hline
\end{tabular}

Opombe. Za razlago oznak testnih dosežkov glej opombe k tabeli 1 . 
Dobljene rezultate bi lahko povezali $\mathrm{z}$ ugotovitvami Moffata idr. (2006), ki poročajo o pozitivni povezavi med uspešnostjo reševanja navigacijske naloge in hitrostjo procesiranja. Tudi Edwards idr. (2013) na vzorcu starejših odraslih po desetih srečanjih poročajo o pomembnem učinku kognitivnega treninga na hitrost procesiranja. Za razliko od naše raziskave, so v omenjeni raziskavi uporabili trening hitrosti procesiranja informacij, kar pomeni, da se je v njihovem primeru pokazal bližnji transfer (reševanje nalog na treningu se je razlikovalo od naloge na začetnem in končnem testiranju, vendar sta obe nalogi primarno zahtevali hitrost procesiranja). V našem primeru so rezultati pokazali na daljni transfer, saj udeleženci niso bili deležni treninga hitrosti procesiranja, temveč treninga prostorske navigacije. Dobljeni rezultati kažejo na pomembno vrednost treninga prostorske navigacije, ki omogoča prenos učinkov na hitrost procesiranja. Hitrost procesiranja je osnovna sestavina kognitivnega delovanja (Musek, 2012) in pomembna komponenta pri reševanju intelektualnih in drugih vsakodnevnih nalog (Leonard idr., 2007), zaradi česar lahko sklepamo, da pri nadarjenih učencih pomembno prispeva $h$ kvaliteti funkcioniranja na kognitivnem področju $\mathrm{v}$ šoli in izven nje.

Vrednosti dosežkov na meri takojšnega priklica vidnoprostorskega spomina (ROCF1) so bile normalno porazdeljene $\mathrm{v}$ obeh skupinah pri prvem in drugem merjenju. Tudi predpostavka o homogenosti varianc je bila izpolnjena, saj se variance dosežkov na ROCF1 med skupinama pri prvem merjenju $(F[1,26]=0,38, p=0,54)$ in pri drugem merjenju $(F[1,26]=0,01, p=0,93)$ niso statistično značilno razlikovale. Pri pregledu grafičnih prikazov smo našli štiri osamelce (enega $\mathrm{v}$ eksperimentalni in enega $\mathrm{v}$ kontrolni skupini na začetnem testiranju ter dva $\mathrm{v}$ kontrolni skupini na končnem testiranju), vendar niso dosegali ekstremnih vrednosti, zato smo jih obdržali v analizi.

Rezultati so pokazali velik učinek interakcije med časom in skupino pri takojšnem vidnoprostorskem priklicu (ROCF1), učinek interakcije je bil blizu statistične značilnosti ( $p=0,052$; slika 4). Parni $t$-test je pokazal statistično značilno razliko $\mathrm{v}$ povprečnih dosežkih na nalogi ROCF1 pred treningom in po njem pri eksperimentalni skupini, pri čemer je Cohenov $d$ pokazal velik učinek. Pri kontrolni skupini je bila razlika med začetnim in končnim testiranjem blizu statistične značilnosti, velikost učinka je bila srednja. $\mathrm{V}$ povezavi $\mathrm{z}$ vidnoprostorskim spominom so nas zanimale tudi razlike med skupinama na odloženem priklicu (ROCF2). Porazdelitev vrednosti dosežkov na testu ROCF2 ni odstopala od normalne $\mathrm{v}$ nobeni od skupin in časovnih točk merjenja, variance dosežkov na ROCF2 med skupinama pri prvem merjenju $(F[1,26]=1,24, p=0,28)$ in pri drugem merjenju $(F[1,26]=0,27, p=0,61)$ se niso razlikovale statistično značilno. Opazili smo štiri osamelce (v vsaki skupini na obeh testiranjih en osamelec), vendar niso dosegali ekstremnih vrednosti, zato smo jih obdržali v analizi.

$\mathrm{V}$ nasprotju s takojšnim priklicem so rezultati pri preverjanju odloženega vidnoprostorskega priklica pokazali izredno majhen učinek interakcije med časom in skupino, prav tako ni bilo statistično značilnega učinka. $\mathrm{Ob}$ upoštevanju mer velikosti učinka lahko zaključimo, da so udeleženci eksperimentalne skupine v primerjavi s kontrolno skupino izboljšali svoje rezultate na meri takojšnjega priklica vidnoprostorskega spomina, medtem ko se izboljšanje na meri odloženega priklica ni pokazalo.

Dobljeni rezultati so le delno skladni s predhodnimi raziskavami (glej van Ekert idr., 2017), ki ugotavljajo prisotnost tako takojšnega kot tudi odloženega priklica vidnoprostorskega spomina med reševanjem navigacijskih nalog. Tudi Moffat idr. $(2001,2006)$ poročajo o pomembni pozitivni povezavi med učenjem poti v virtualnem labirintu in vidnoprostorskim spominom. O prisotnosti vidnoprostorskih sposobnosti med prostorskim navigiranjem poročajo tudi Fenner idr. (2000), ki so na vzorcu 20 otrok, starih med 5 in 10 let, ugotovili, da tisti, ki imajo visoko izražene vidnoprostorske sposobnosti (sposobnost mentalne rotacije in obseg vidnoprostorskega spomina) uspešneje rešujejo navigacijske naloge v primerjavi z njihovimi vrstniki z nižje izraženimi vidnoprostorskimi sposobnostmi. Podobno so ugotovili Nori idr. (2006) na vzorcu odraslih, starih med 19 in 32 let, kjer je naloga prostorske navigacije potekala $\mathrm{v}$ naravnem okolju. Rezultati so pokazali, da posamezniki, ki imajo višje izražene vidnoprostorske sposobnosti, bolj uspešno najdejo pravilno pot do cilja, in sicer naredijo statistično pomembno manj napak, se redkeje obotavljajo in prej pridejo do cilja. Delno skladnost s predhodnimi rezultati bi lahko pripisali temu, da so omenjene raziskave preverjale prisotnost takojšnjega in odloženega vidnoprostorskega spomina med reševanjem navigacijske naloge, medtem ko smo $\mathrm{v}$ naši raziskavi preverjali učinke treninga na izboljšanje vidnoprostorskega spomina. Tako se zdi, da ima trening prostorske navigacije hitrejši učinek na izboljšanje takojšnjega priklica vidnoprostorskega spomina v primerjavi z odloženim priklicem.

Dobljene rezultate o učinku takojšnjega vidnoprostorskega priklica bi lahko povezali z ugotovitvami G. Janzen in sodelavcev (2008), ki pravijo, da je uspešnost iskanja poti, ki jo le enkrat prehodimo, v veliki meri odvisna od uspešnosti shranjenih informacij o navigaciji. Pri tem igra pomembno vlogo vidnoprostorski spomin, ki med navigiranjem po novi poti omogoča shranjevanje relevantnih informacij o prostoru in njihov priklic ob ponovnem navigiranju po tej isti poti. $\mathrm{V}$ naši raziskavi so morali udeleženci v kognitivnem treningu na vsaki naslednji težavnostni stopnji poiskati novo pot do cilja in to isto pot dvakrat zapored ponoviti brez napake. $\mathrm{Na}$ podlagi značilnosti naloge in predhodnih ugotovitev lahko sklepamo, da je trening pri udeležencih spodbujal delovanje vidnoprostorskega spomina, ki se je nanašal na takojšni priklic shranjenih prostorskih informacij o novih poteh na posamezni težavnostni stopnji. Udeleženec je moral ob vsakem križišču pravilno priklicati smer, ki vodi do naslednjega križišča, in smeri, ki vodijo v slepo ulico.

Pri ostalih odvisnih spremenljivkah je bil učinek interakcije med časom in skupino majhen in statistično nepomemben.

\section{Splošna razprava}

Ob primerjavi vseh dobljenih rezultatov lahko opazimo, da so se povprečni rezultati na vseh kognitivnih testih pri obeh skupinah izboljšali. Izjemo predstavlja le povprečen 


\section{Slika 3}

Povprečne vrednosti dosežkov na TMT_A pri eksperimentalni in kontrolni skupini na začetnem in končnem testiranju

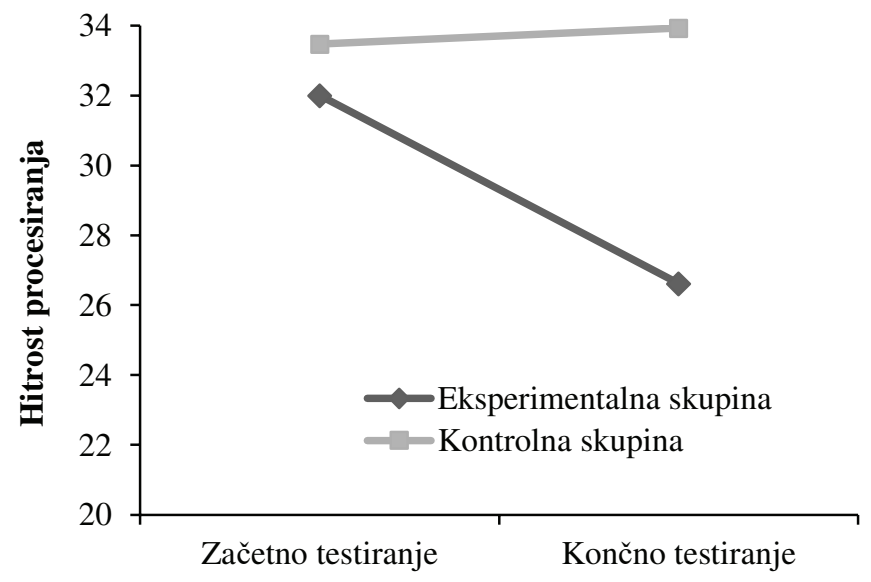

Čas merjenja

\section{Slika 4}

Povprečne vrednosti dosežkov na ROCF1 pri eksperimentalni in kontrolni skupini na začetnem in končnem testiranju

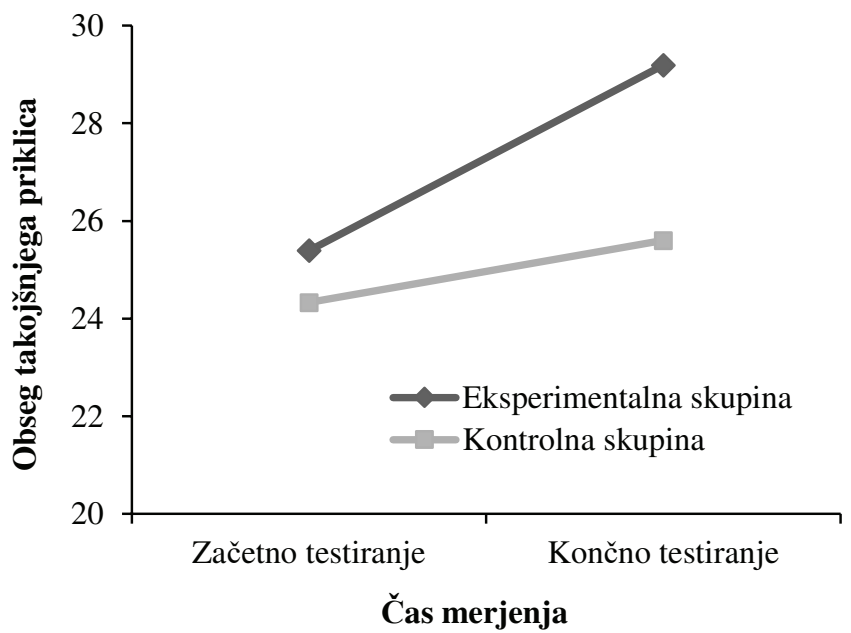

je tudi, da se transfer pri različnih kognitivnih sposobnostih pokaže po različnem časovnem obsegu treninga.

Kljub temu da smo izmed nadarjenih učencev izbrali samo tiste, ki so na testu inteligentnosti dosegli vsaj nadpovprečen rezultat, je ostal vzorec relativno heterogen, saj so bili v raziskavo vključeni učenci, ki so bili identificirani kot nadarjeni na različnih področjih (intelektualnem, ustvarjalnem, učnem, umetniškem in/ali telesno-gibalnem področju). Vzorec učencev $\mathrm{z}$ visokimi kognitivnimi sposobnostmi pa je lahko tudi vzrok, da dobljeni rezultati na končnem testiranju pri večini mer niso pokazali pomembnih učinkov treninga. Obstaja možnost, da se transfer ne pokaže, kadar posameznik že pred začetkom treninga dosega nadpovprečne kognitivne sposobnosti. Po pregledu literature nismo zasledili raziskave, ki bi preverjala učinke kognitivnega treninga na skupini nadarjenih učencev, zato do sedaj še ni znano, kakšna intenzivnost in časovna dolžina treninga bi bila primerna za doseganje učinkov pri nadarjenih učencih.

\section{Omejitve in smernice za prihodnje raziskave}

ni pokazal. Lee idr. (2012) namreč poročajo, da je lahko razlog za neuspešen transfer kognitivnega treninga na druge sposobnosti, ki niso neposredno trenirane, nezadostna vaja na treniranih nalogah. Naša intervencija je obsegala osem srečanj, kar je manj, kot po poročanju Kavčiča (2015) navajajo nekatere raziskave, ki pravijo, da je za viden učinek potrebnih najmanj 15 srečanj, ki bi se naj zvrstila v obdobju dveh mesecev. Kljub temu so v raziskavah $\mathrm{z}$ enakim številom in intenzivnostjo treningov poročali o pomembnih učinkih treninga; npr. v raziskavi J. L. Mozolic in sodelavcev (2011) je kognitivni trening selektivne pozornosti zajemal enake časovne okvirje, kot smo jih uporabili $\mathrm{v}$ naši raziskavi $(8$ srečanj po enkrat na teden), pričemer se je po treningu pokazalo statistično pomembno izboljšanje na netreniranih nalogah hitrosti procesiranja, izvršilnih funkcij in delovnega spomina eksperimentalne skupine $\mathrm{v}$ primerjavi s kontrolno. Možno
Nekateri uporabljeni pripomočki ne dosegajo visoke zanesljivosti, kar je omejitev naše raziskave. Potrebno je upoštevati tudi možnost vpliva drugih dejavnikov, ki jih nismo preverili, na dosežke. Omejitev raziskave je tudi majhen vzorec. Poleg tega je bila raziskava izvedena na udeležencih, ki so prihajali iz iste šole (iz petih oddelkov), kar omejuje posplošitev rezultatov.

Ker so rezultati nakazali izboljšanje kognitivnih sposobnosti (parni $t$-testi so na vseh merah pokazali statistično pomemben napredek pri eksperimentalni skupini učinke po daljši izpostavljenosti treningu. Prav tako bi bilo dobro udeležence testirati tudi po daljšem časovnem obdobju zaključenega treninga in tako preveriti dolgoročne učinke. na končnem testiranju), bi bilo smiselno v prihodnje preverjati 
$\mathrm{V}$ prihodnje bi bilo zanimivo preveriti, ali prihaja do razlik $\mathrm{v}$ učinkovitosti kognitivnega treninga prostorske navigacije med posamezniki, ki uporabljajo drugačne strategije reševanja navigacijskih nalog. Kraemer idr. (2017) namreč ugotavljajo, da strategije, povezane $z$ verbalnim ali vizualnim kognitivnim stilom, vplivajo na sposobnost navigacije $\mathrm{v}$ neznanem okolju. Posameznik, ki v pretežni meri uporablja vizualno strategijo, bo s pomočjo vidnoprostorskih spretnosti našel pot do cilja na podlagi predstavljanja povezane mreže prostorskih oznak od začetka do konca poti. Na drugi strani si bo posameznik, ki uporablja verbalno strategijo, za pomnjenje prostorskih oznak pomagal z besednim spominom (npr. ko pridem do prve oznake, zavijem levo, nato grem naravnost, dokler ne pridem do naslednje oznake in zavijem desno). Tako se zdi, da so med treningom pri posameznikih, ki uporabljajo različne strategije, aktivirane različne kognitivne sposobnosti, kar bi morda lahko vplivalo na prenos učinkov na specifične kognitivne sposobnosti (npr. na besedni ali vidnoprostorski spomin). Prav tako bi bilo $\mathrm{v}$ prihodnje zanimivo preveriti razlike $v$ spolu glede uporabe strategij reševanja navigacijskih nalog in učinkovitosti kognitivnega treninga.

\section{Zaključek}

Dobljeni rezultati so pokazali, da lahko že s kratkotrajnim treningom prostorske navigacije izboljšamo hitrost procesiranja, velik učinek interakcije med časom in skupino se je pokazal tudi pri takojšnem priklicu vidnoprostorskega spomina.

Trening prostorske navigacije se je pokazal kot primeren za nadarjene učence, ki obiskujejo peti in šesti razred osnovne šole. $Z$ izjemo učenca, ki je trening zaradi nemotiviranosti predčasno zapustil, so se učenci radi udeleževali srečanj in so bili motivirani za reševanje navigacijskih nalog. Ocenjujemo, da je nanje spodbudno delovalo stopnjevanje težavnosti glede na individualne dosežke. Zaznali smo tudi tekmovalnost med učenci, kar je verjetno dodatno prispevalo $\mathrm{k}$ vztrajanju na treningu. Ocenjujemo, da so bile navigacijske naloge primerno zahtevne in da je reševanje računalniških nalog na učence delovalo spodbudno.

$\mathrm{Ob}$ potencialni možnosti, ki jo nakazujejo dobljeni rezultati, da lahko s kognitivnim treningom prostorske navigacije izboljšamo nekatere kognitivne sposobnosti, se zdi tak kognitivni trening uporaben kot oblika dela z nadarjenimi učenci, ki kažejo potencial na določenem področju (npr. intelektualnem, ustvarjalnem, učnem, umetniškem ali telesno-gibalnem področju) in hkrati dosegajo vsaj nadpovprečen rezultat na testu inteligentnosti.

\section{Literatura}

Anga, S. Y., Leea, K., Cheamb, F., Poona, K. in Koha, J. (2015). Updating and working memory training: Immediate improvement, long-term maintenance and generalisability to non-trained tasks. Journal of Applied Research in Memory and Cognition, 4(2), 121-128.
Barnes, J. J., Nobre, A. C., Woolrich, M. W., Baker, K. in Astle, D. E. (2016). Training working memory in childhood enhances coupling between frontoparietal control network and task-related regions. The Journal of Neuroscience, 36(34), 9001-9011.

Bohbot, V. D., McKenzie, S., Konishi, K., Fouquet, C., Kurdi, V., Schachar, R., Boivin, M. in Robaey, P. (2012). Virtual navigation strategies from childhood to senescence: Evidence for changes across the life span. Frontiers in Aging Neuroscience, 4, članek 28.

Cohen, J. (1992). A power primer. Psychological Bulletin, 112(1), 155-159.

Edwards, J. D., Wadley, V. G., Vance, D. E., Wood, K., Roenker, D. L. in Ball, K. K. (2013). The impact of speed of processing training on cognitive and everyday performance. Aging and Mental Health, 9(3), 262-271.

Fenner, J., Heathcote, D. in Smith, J. J. (2000). The development of wayfinding competency: Asymmetrical effects of visuo-spatial and verbal ability. Journal of Environmental Psychology, 20(2), 165-175.

Goldstein, G. in Watson, J. R. (1989). Test-retest reliability of the Halstead- Reitan Battery and the WAIS in a neuropsychiatric population. Clinical Neuropsychologist, 3(3), 265-272.

Gray, S. A., Chaban, P., Martinussen, R., Goldberg, R., Gotlieb, H., Kronitz, R., Hockenberry, M. in Tannock, R. (2012). Effects of a computerized working memory training program on working memory, attention, and academics in adolescents with severe LD and comorbid ADHD: A randomized controlled trial. Journal of Child Psychology and Psychiatry, 53(12), 1277-1284.

Hötting, K., Holzschneider, K., Stenzel, A., Wolbers, T. in Röder, B. (2013). Effects of a cognitive training on spatial learning and associated functional brain activations. BMC Neuroscience, 14, članek 73.

Janzen, G., Jansen, C. in van Turennout, M. (2008). Memory consolidation of landmarks in good navigators. Hippocampus, 18(1), 40-47.

Juriševič, M. (2011). Vzgoja in izobraževanje nadarjenih [Educaton of gifted students]. V J. Krek in M. Metljak (ur.), Bela knjiga o vzgoji in izobraževanju v Republiki Sloveniji 2011 [White paper on education in the Republic of Slovenia] (str. 329-345). Zavod RS za šolstvo.

Kaufman, A. S. (1994). Intelligent testing with WISC-III. Wiley.

Kavčič, V. (2015). Umovadba za bistre možgane v poznih letih [Cognitive training for smart brains in old age]. Miš.

Kraemer, D. J. M., Schinazi, V. R., Cawkwell, P. B., Tekriwal, A., Epstein, R. A. in Thompson-Schill, S. L. (2017). Verbalizing, visualizing, and navigating: The effect of strategies on encoding a large-scale virtual environment. Journal of Experimental Psychology: Learning, Memory, and Cognition, 43(4), 611-621.

Lee, H., Boot, W. R., Basak, C., Voss, M. W., Prakash, R. S., Neider, M., Erickson, K. I., Simons, D. J., Fabiani, M., Gratton, G., Low, K. A., Kramer, A. F. (2012). Performance gains from directed training do not transfer to untrained tasks. Acta Psychologica, 139(1), 146-158. 
Leonard, L. B., Ellis, W. S., Miller, C. A., Francis, D. J., Tomblin, J. B. in Kail, R. V. (2007). Speed of processing, working memory, and language impairment in children. Journal of Speech, Language, and Hearing Research, 50(2), 408-428.

Lezak, M. D., Howieson, D. B., Bigler, E. D. in Tranel, D. (2012). Neuropsychological assessment (5. izd.). Oxford University Press.

Lövdén, M., Schaefera, S., Noacka, H., Bodammera, N. C., Kühnd, S., Heinzef, H. J., Düzelf, E., Bäckmana, L. in Lindenbergera, U. (2012). Spatial navigation training protects the hippocampus against age-related changes during early and late adulthood. Neurobiology of Aging, 33(3), 620.e9-620.e22.

Marusic, U., Giordani, B., Moffat, S. D., Petrič, M., Dolenc, P., Pišot, R. in Kavcic, V. (2016). Computerized cognitive training during physical inactivity improves executive functioning in older adults. Aging, Neuropsychology, and Cognition, 25(1), 49-69.

McCarney, R., Warner, J., Iliffe, S., Haselen, R., Griffin, M. in Fisher, P. (2007). The Hawthorne effect: a randomised, controlled trial. BMC Medical Research Methodology, 7(1), 1-8.

Michigan State University, Games for Entertainment and Learning Lab. (2016). Brain Powered Games: Maze Training [računalniški program]. https:// brainpoweredgames.msu.edu/

Miller, J. F., Neufang, M., Solway, A., Brandt, A., Trippel, M., Mader, I., Hefft, S., Merkow, M., Polyn, S. M., Jacobs, J., Kahana, M. J. in Schulze-Bonhage, A. (2013). Neural activity in human hippocampal formation reveals the spatial context of retrieved memories. Science, 342(6162), 1111-1114.

Moffat, S. D. (2009). Aging and spatial navigation: What do we know and where do we go? Neuropsychology Review, 19(4), 478-489.

Moffat, S. D., Kennedy, K. M., Rodrigue, K. M. in Raz, N. (2006). Extrahippocampal contributions to age differences in human spatial navigation. Cerebral Cortex, 17(6), 1274-1282.

Moffat, S. D., Zonderman, A. B. in Resnick, S. M. (2001). Age differences in spatial memory in a virtual environment navigation task. Neurobiology of Aging, 22(5), 787-796.

Mozolic, J. L., Long, A. B., Morgan, A. R., Payne, M. R. in Laurienti, P. J. (2011). A cognitive training intervention improves modality-specific attention in a randomized controlled trial of healthy older adults. Neurobiology of Aging, 32(4), 655-668.

Musek, J. (2012). Kognitivne sposobnosti: Sodobni pogled na njihovo strukturo in njihovo povezanost s starostjo in intelektualnim staranjem [Cognitive abilities: A recent look at their structure and their connections with age and intellectual aging]. Anthropos, 44(3/4), 103-123.

Nori, R., Grandicelli, S. in Giusberti, F. (2006). Visuo-spatial ability and wayfinding performance in real-world. Cognitive Processing, 7(1), 135-137.

Novak, M. (2003). Aktivne oblike dela z nadarjenimi učenci [Active forms of work with gifted students]. V M. Blažič (ur.), Nadarjeni med teorijo in prakso [The gifted between theory and practice] (str. 318-329). Slovensko združenje za nadarjene.

Piccardi, L., Palermo, L., Bocchi, A., Guariglia, C. in D'Amico, S. (2015). Does spatial locative comprehension predict landmark-based navigation? PloS One, 10(1), članek e0115432.

Richardson, J. T. E. (2011). Eta squared and partial eta squared as measurements of effect size in educational research. Educational Research Review, 6(2), 135-147.

Strauss, E., Sherman, E. M. S. in Spreen, O. (2006). A compendium of neuropsychological tests: Administration, norms, and commentary (3. izd.). Oxford University Press.

Tom, C. in Tversky, B. (2012). Remembering routes: Streets and landmarks. Applied Cognitive Psychology, 26(2), 182-193.

van Ekert, J., Wegman, J., Jansen, C., Takashima, A. in Janzen, G. (2017). The dynamics of memory consolidation of landmarks. Hippocampus, 27(4), 393-404.

Wechsler, D. (2001). WISC-IIIII: Wechslerjeva lestvica inteligentnosti za otroke: Priročnik [WISC-III ${ }^{\mathrm{SI}}$ Wechsler Intelligence Scale for Children: Manual]. Center za psihodiagnostična sredstva.

Willis, S. L. in Schaie, K. W. (2009). Cognitive training and plasticity: Theoretical perspective and methodological consequences. Restorative Neurology and Neuroscience, 27(5), 375-389.

Wolbers, T. in Hegarty, M. (2010). What determines our navigational abilities? Trends in Cognitive Sciences, 14(3), 138-146.

Žagar, D. (2012). Drugačni učenci [Different students]. Znanstvena založba Filozofske fakultete. 